\title{
Arterial Stiffness and Chronic Kidney Disease
}

\author{
Anne-Sophie Garnier Marie Briet \\ INSERM U1083, CNRS UMR 6214, Centre Hospitalo-Universitaire d'Angers, Université \\ d'Angers, Angers, France
}

\section{Key Words}

Chronic kidney disease $\cdot$ Stiffness $\cdot$ Remodeling $\cdot$ Artery

\begin{abstract}
Chronic kidney disease (CKD) is a major public health concern due to the high prevalence of associated cardiovascular (CV) disease. CV mortality is 10-30 times higher in end-stage renal disease patients than in the age-adjusted general population. The last 20 years have been marked by a huge effort in the characterization of the vascular remodeling process associated with CKD and its consequences on the renal, CV and general prognosis. By comparison with patients with normal renal function, with or without hypertension, an increase in large artery stiffness has been described in end-stage renal disease as well as in CKD stages 2-5. Most clinical studies are consistent with the observation that damage to large arteries may contribute to the high incidence of CV disease. By contrast, the impact of large artery stiffening and remodeling on CKD progression is still a matter of debate. Concomitant exposure to other $\mathrm{CV}$ risk factors, including diabetes, seems to play a major role in the association between aortic stiffness and estimated GFR. The conflicting results obtained from longitudinal studies designed to evaluate the impact of baseline aortic stiffness on GFR progression are detailed in the present review. Only pulse pressure, central and peripheral, is almost constantly associated with incident CKD and GFR decline. Kidney transplantation improves patients' CV prognosis, but its impact on arterial stiffness is still controversial. Donor age, living kidney donation and mean blood pressure appear to be the main determinants of improvement in aortic stiffness after kidney transplantation.

(C) 2016 S. Karger AG, Basel
\end{abstract}




\section{Introduction}

The growing prevalence of chronic kidney disease (CKD) and the severity of the comorbidities associated with this disease help identify CKD as a major public health concern. CKD is defined as abnormalities of kidney structure and/or function, present for at least 3 months, with implications for health (table 1) [1]. Incidence and prevalence differ between countries from 10 to 20\%. Within countries, subgroups are at increased risk of developing CKD; for example, Black and Asian people in the UK, and Black, Hispanic and Native Americans in the United States [1,2]. In developed countries, hypertension and diabetes contribute mainly to the occurrence of CKD, whereas in Asia, glomerulonephritis and unknown origins are mostly observed. In countries with low outcome, infectious diseases represent a common cause. Genetic abnormalities, including variations in MYH9 and APOL1, which are associated with nondiabetic CKD in African patients [3], and environmental factors such as analgesic abuse or herbal medications [3], are also involved.

The severity of CKD is mostly due to the high prevalence of cardiovascular (CV) disease. CKD patients are more likely to die from $\mathrm{CV}$ disease than progress to end-stage renal disease (ESRD), requiring dialysis or transplantation [4]. CV mortality is 10-30 times higher in ESRD patients than in the age-adjusted general population; 30-60\% of ESRD patients die from CV diseases [5]. In earlier stages, the risk of fatal or nonfatal CV events increases inversely with the level of estimated GFR (eGFR) [6] below the threshold of $75 \mathrm{ml} / \mathrm{min} / 1.75 \mathrm{~m}^{2}$ and/or with the level of albumin-to-creatinine ratio above the threshold of $5 \mathrm{mg} / \mathrm{g}$ [7]. The presence of residual renal function, even at a low level, is associated with a lower mortality risk in hemodialysis patients [8], underlying the impact of kidney function on CV prognosis. Furthermore, the presence of $\mathrm{CV}$ disease worsens the short- and long-term prognosis of CKD [8] as shown in a recent large cohort study comprising 2,964 CKD patients, with a follow-up time of 2.76 years, where CV events were associated with a significant increase in the risk of ESRD and all-cause mortality before ESRD [9].

The high prevalence of traditional CV risk factors in CKD patients, such as diabetes and hypertension, partly explains these observations. Indeed, the association between CV events and GFR persists after adjustment with traditional CV risk factors, emphasizing the role of CKD per se. In addition, in advanced stages of CKD, interventional trials targeting traditional CV risk factors failed to improve survival [10-13]. These observations suggest that nontraditional uremia-linked risk factors, including mineral bone disorders, anemia, increased activity of the renin-angiotensin system and sympathetic nerve activity, inflammation and oxidative stress, may play a significant role in the increased CV risk observed in CKD patients [14]. This uremia milieu, including toxins and accumulation of posttranslational modified proteins, affects vascular tissue and impacts vascular geometric and functional properties.

Table 1. CKD stages following K-DIGO 2012 guidelines (Clinical Practice Guideline for the Evaluation and Management of Chronic Kidney Disease)

\begin{tabular}{lccc}
\hline Stage & $\begin{array}{l}\text { eGFR, } \\
\mathrm{ml} / \mathrm{min} / 1.73 \mathrm{~m}^{2}\end{array}$ & Stage & $\begin{array}{l}\text { ACR, } \\
\mathrm{mg} / \mathrm{mmol}\end{array}$ \\
\hline 1 & $>90$ & $\mathrm{~A} 1$ & $<3$ \\
2 & $60-89$ & $\mathrm{~A} 2$ & $3-30$ \\
$3 \mathrm{~A}$ & $45-59$ & $\mathrm{~A} 3$ & $>30$ \\
$3 \mathrm{~B}$ & $30-44$ & & \\
4 & $15-29$ & & \\
5 & $<15$ & \\
\hline \multicolumn{3}{c}{ ACR = Albumin-to-creatinine ratio. } \\
\hline
\end{tabular}


The last 20 years were marked by a huge effort in the characterization of the vascular remodeling process associated with CKD and its consequences on renal, CV and general prognosis. If the majority of the clinical studies are consistent with the observation that large artery damage may contribute to the high incidence of CV diseases [15-18], the impact of large artery remodeling on CKD progression is still a matter of debate. In the present review, we will describe the large artery remodeling observed in CKD and its impact on renal, CV and general prognosis (table 2). The discrepancies between clinical studies about the relationship between arterial remodeling and stiffening and CKD progression will be discussed.

\section{Arterial Stiffening and Remodeling, General View}

The physiological and pathophysiological roles of arterial stiffness have been widely described in several reviews [19-21] as well as the methodological issues concerning the measurement of stiffness and remodeling parameters [22-24]. The basic principles will be only briefly described in the present review.

The two main functions of the arterial system are to ensure adequate blood flow transmission to tissues and organs - the conduit function - and to buffer pressure and pulsatile flow oscillations - the cushioning function. The efficiency of these functions depends on the geometric and viscoelastic properties of the arterial system. The cushioning function can be defined as the ability of the large arteries to buffer pressure and to transform cyclic blood flow in the aorta into continuous capillary flow. An increase in large artery stiffness is associated with an increase in cardiac work, arterial pressure oscillation transmission to the microcirculation and organ damage, including the kidneys [19, 21] (fig. 1). In agreement with these observations, many studies have emphasized the impact of arterial stiffness on CV and general prognosis in different populations, including patients with diabetes, hypertension and the general population [16, 25-28].

In addition to arterial stiffening, the arterial wall undergoes a remodeling process in response to an increase in pressure or flow, in order to normalize circumferential wall stress. Circumferential wall stress $(\mathrm{kPa})$ is calculated according to the Lamé equation as mean blood pressure $\times$ radius/thickness. The spectrum of structural alteration in response to an increase in pressure includes hypertrophic inward or outward remodeling resulting from an increase in muscle mass and eutrophic remodeling resulting from the rearrangement of cellular and noncellular elements [29].

Fig. 1. Schematic representation of the role of aortic stiffness in assuring blood flow through the peripheral circulation. Reprinted from Briet et al. [19] with permission from Elsevier.

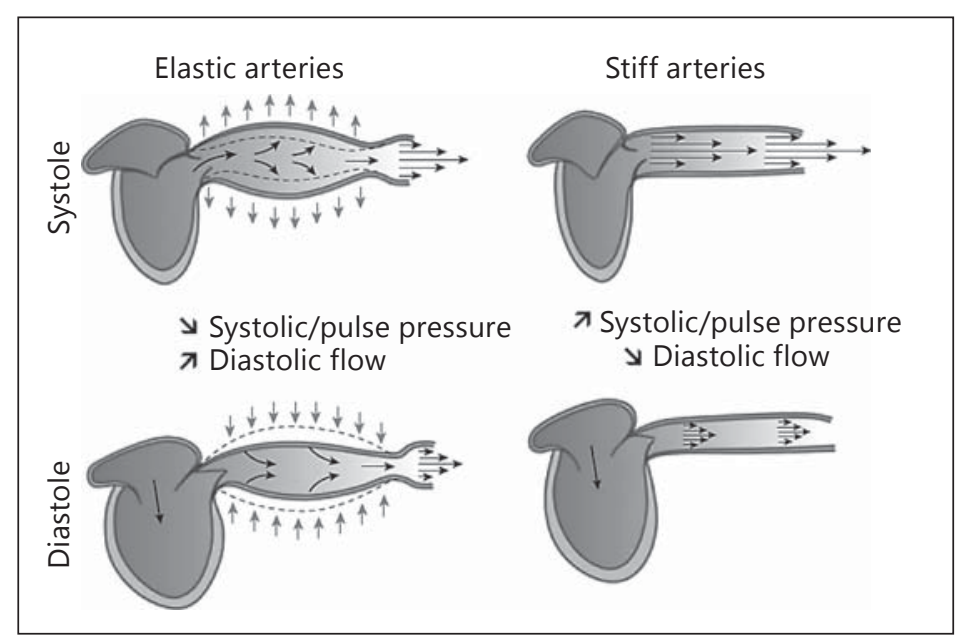




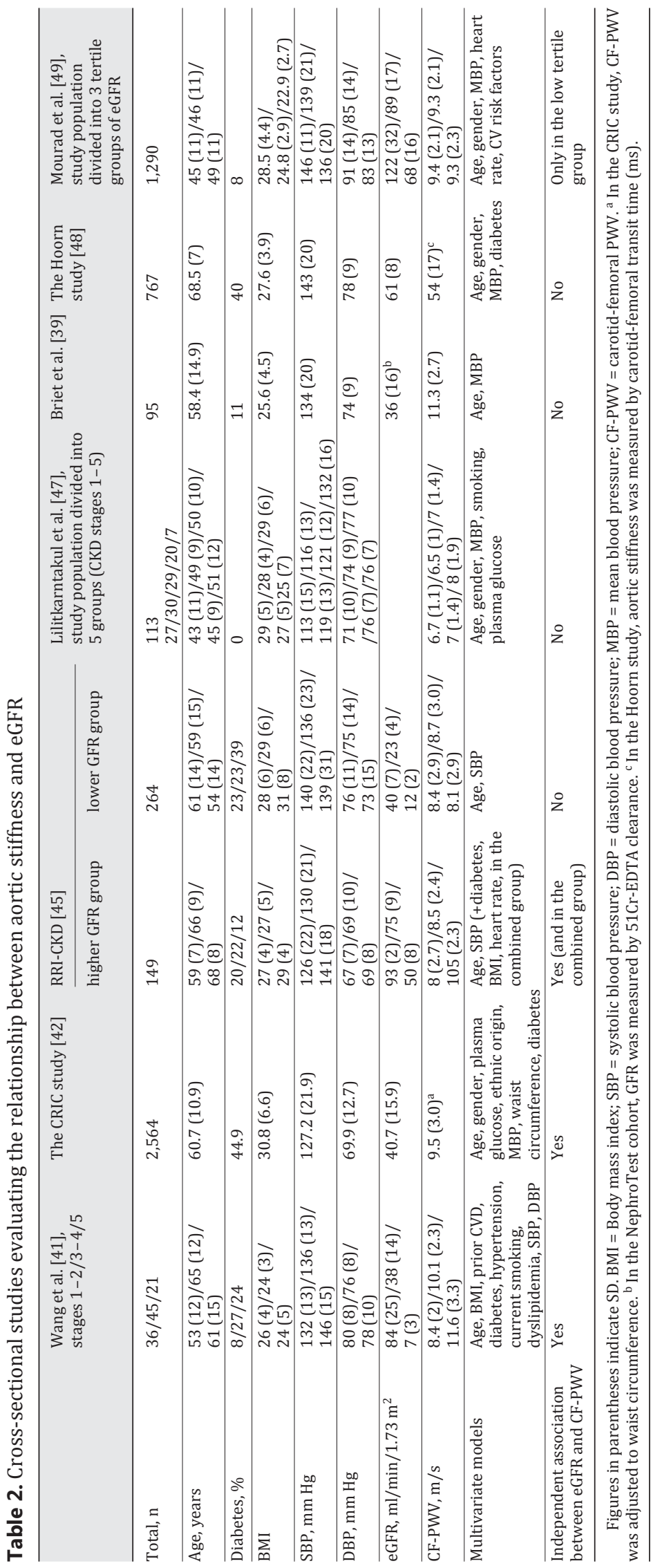


Arterial stiffness can be directly measured regionally and locally. Carotid-femoral pulse wave velocity (PWV) measurement has been recommended by expert consensus as the most simple, robust and reproducible method [23]. Carotid-femoral PWV evaluates the elastic properties of the descending and abdominal aorta and the iliofemoral segment. It is calculated from the measurements of pulse transit time (seconds) and distance (meters) travelled by the pulse between the carotid recording site and the femoral recording site using the footto-foot velocity method. Reference values have been recently published in a large collaborative study of 16,867 subjects and patients [30]. Carotid-femoral PWV measurement was recommended for the management of hypertension by the 2007 [31] and 2013 [32] European Society of Hypertension - European Society of Cardiology Guidelines. An interface is now available to assess a given measurement of arterial stiffness relative to known reference values [33].

Local arterial stiffness and remodeling can be measured noninvasively by high-resolution echotracking systems on the femoral, brachial, radial and carotid arteries. These devices have been developed to measure intima-media thickness, internal diameter and stroke change in diameter with a high level of precision. Simultaneous measurements of central pulse pressure and stroke change in cross-sectional areas are used to calculate arterial distensibility.

In the present review, we will focus on aortic stiffness measured by carotid-femoral PWV in CKD patients and its impact on renal and CV prognosis.

\section{Aortic Stiffness and CKD}

In $\mathrm{CKD}$, the most common arterial lesions are both occlusive lesions affecting the intima - atherosclerosis - and remodeling lesions affecting the media - arteriosclerosis - resulting in an increase in arterial stiffness and diameter [34]. Atherosclerosis is highly prevalent in CKD patients [35] with specific features of atherosclerotic plaques characterized by a higher prevalence of calcified plaques and the importance of inflammatory markers. In the present review, we will focus on arteriosclerotic lesions.

\section{Aortic Stiffness and ESRD}

In stage 5 CKD patients in dialysis, blood pressure profile is characterized by an increase in systolic blood pressure with normal or low diastolic blood pressure resulting in an increase in pulse pressure [36]. This blood pressure pattern is consistently associated with an increase in large artery stiffness, as extensively described by London et al. [15]. Arterial stiffening is more pronounced in central arteries relative to peripheral muscular arteries, resulting in accelerated reduction in impedance mismatch and of buffering capacity to lower pulsatile pressure transmission to peripheral microcirculation [19]. Fortier et al. [37] recently demonstrated that aortic-brachial arterial stiffness mismatch was strongly and independently associated with increased mortality in ESRD patients. Arterial stiffening progresses rapidly over time in hemodialysis patients. The annual rate of change in carotid-femoral PWV was 0.84 $\mathrm{m} / \mathrm{s}$ per year [ $95 \%$ confidence interval (CI), $0.50-1.12 \mathrm{~m} / \mathrm{s}$ per year] in a prospective cohort of 109 hemodialysis patients with a mean follow-up of 1.2 years [38].

\section{Aortic Stiffness and CKD Stages 2-5}

An increase in aortic stiffness was also observed at earlier stages, from stage 2 to 5 , compared with hypertensive patients or healthy subjects, as shown in the NephroTest cohort [39] or by Shinohara et al. [40]. Within the CKD population, conflicting results have been published regarding the association between GFR levels and aortic PWV (table 1). Wang et al. 
[41] studied the relationship between carotid-femoral PWV and eGFR in 102 patients with stage 1-5 CKD and showed a significant trend for a stepwise increase in carotid-femoral PWV corresponding to CKD stages. In the multivariate model, decreased eGFR was independently associated with an increase in carotid-femoral PWV. An independent association between eGFR and carotid-femoral PWV adjusted for waist circumference was also shown in 2,564 patients (mean age $60.7 \pm 10.9$ years, mean eGFR $40.7 \pm 15.9 \mathrm{ml} / \mathrm{min} / 1.73 \mathrm{~m}^{2}$ ) from the CRIC (Chronic Renal Insufficiency Cohort) ancillary study [42]. In the CRIC study, carotid-femoral PWV was also an independent determinant of proteinuria in the whole study population $(\mathrm{n}=$ $2,144)[43]$. The independent association between arterial stiffness and eGFR in CKD patients has been confirmed in other clinical studies [44] including the RRI (Renal Research Institute)CKD study [45]. However, the relationship between aortic stiffness and GFR is not so obvious. For example, in the RRI-CKD study, two groups of patients were considered regarding the level of GFR: a higher GFR group (eGFR between 60 and $90 \mathrm{ml} / \mathrm{min} / 1.73 \mathrm{~m}^{2}$ ) and a lower GFR group (eGFR between 60 and $5 \mathrm{ml} / \mathrm{min} / 1.73 \mathrm{~m}^{2}$ ). Interestingly, after adjustment for age and systolic blood pressure, an independent association between carotid-femoral PWV and eGFR was seen only in the higher GFR group but not in the lower GFR group. The same observation was made in the NephroTest study where eGFR was an independent determinant of PWV only in the whole population, including CKD patients and hypertensive patients with eGFR $>60 \mathrm{ml} /$ $\min / 1.73 \mathrm{~m}^{2}(\mathrm{n}=216)$, but not within the CKD population $(\mathrm{n}=95)$ [39]. In the NephroTest cohort, longitudinal follow-up of aortic stiffness progression in CKD patients confirmed the results of the cross-sectional study in this population with an absence of aortic stiffness progression during CKD progression [46]. In a population of Scottish CKD patients with minimal comorbidities, the significant association between eGFR and aortic PWV seen in univariate analyses disappeared after adjustment for CV risk factors [39, 47], emphasizing the effect of comorbidities on arterial stiffening in CKD patients.

The relationship between aortic stiffness and eGFR was also assessed in cohorts with less severe impairment of renal function. 767 patients with reduced renal function (mean eGFR $60.6 \mathrm{ml} / \mathrm{min} / 1.73 \mathrm{~m}^{2}$ ) were studied within the framework of the Hoorn study [48]. No independent association was found between eGFR and aortic stiffness. Conversely, in a population study performed by Mourad et al. [49] involving 1,290 subjects with normal and impaired kidney function, an inverse relationship between eGFR and carotid-femoral PWV was only seen in those with the lowest tertile of eGFR.

The main differences between these clinical studies are the number of included patients which varies from 50 to 2,564 [42,44] and the clinical characteristics of the study populations (table 2). In all of these studies, except in the Hoorn study, arterial stiffness was evaluated by carotid-femoral PWV measurement using a tonometer, the gold standard method according to expert consensus documents [23, 24]. However, in the CRIC study, adjustment to waist circumference was added because they showed an artifactual increase in carotid-femoral distances in patients with large waist circumferences. This procedure did not impact the relationship between eGFR and carotid-femoral PWV [42]. The main clinical characteristics of the patients included in the clinical studies described above are detailed in table 2 . Briefly, the study populations are not all comparable in terms of comorbidities. The patients included in most of the studies showing no independent association between carotid-femoral PWV and eGFR are characterized by the low prevalence of comorbidities. The most remarkable difference between studies is the proportion of diabetic patients, which goes from 0 [47] and $11 \%$ in the NephroTest cohort [39] to $45 \%$ in the CRIC study [42]. The observations made by Weir et al. [43] in the CRIC study illustrate the importance of diabetes in the relationship between aortic stiffness and kidney damage. Indeed, they showed that carotid-femoral PWV was an independent determinant of proteinuria in the subgroup of diabetic patients but not in nondiabetic patients. 
In addition, it is worth noticing that in most of these studies, the variation in PWV explained by eGFR is very low, around $2 \%[39,45]$. Most of the variation was explained by age and CV risk factors. The higher PWV observed among CKD patients might be primarily due to $\mathrm{CV}$ risk factors rather than renal impairment per se. Individual meta-analysis could help to disentangle the impact of CV risk factors on the relationship between eGFR and aortic stiffness.

\section{Impact of Aortic Stiffness on CKD Progression}

Kidney perfusion is physiologically characterized by low resistance and high flow. Glomerular capillaries are protected from the barotrauma induced by increases in blood pressure by a combination of two autoregulatory mechanisms, a faster myogenic and a slower tubuloglomerular feedback system. However, pathological situations such as sustained hypertension, kidney disease or vascular damage alter these protective mechanisms. Renal autoregulatory impairment may enhance susceptibility to hypertensive renal injury [50]. According to these physiological principles, increase in aortic stiffness should be associated with faster GFR decline. However, as detailed below, conflicting results have been published about the impact of arterial stiffness on CKD progression in CKD cohorts (table 3).

In the NephroTest cohort, 180 patients were included in a longitudinal follow-up (4.6 years) study of arterial parameters, measured GFR $\left({ }^{51} \mathrm{Cr}\right.$-EDTA renal clearance) and CV event recording. No association was shown between baseline aortic stiffness and GFR decline in a mixed model regression analysis [46]. The same observation was made by Baumann et al. [51] in a cohort of 135 CKD patients (mean follow-up 42 months, mean eGFR $41.1 \mathrm{ml}$ / $\mathrm{min} / 1.73 \mathrm{~m}^{2}$ ). On the other hand, in a prospective cohort (follow-up 1.5 years) of 120 patients (mean age $69 \pm 12$ years) at stages $3-4$ CKD (baseline eGFR $32 \pm 11 \mathrm{ml} / \mathrm{min} / 1.73 \mathrm{~m}^{2}$ ), aortic PWV was significantly associated with the gradient of reciprocal creatinine plot, monitoring change in eGFR. In this study, aortic PWV was also an independent predictor of the combined renal endpoint of $>25 \%$ decline in eGFR or initiation of renal replacement therapy. It is worth noticing that age and basal eGFR were not included in the stepwise multiple linear regression model of factors independently associated with the decline of renal function [52]. More generally, confounding parameters included in the multivariate models vary among studies (table 3). An effort towards standardization could help compare the results of these studies. Longitudinal data from the CRIC study will provide useful information about the impact of aortic stiffness on CKD progression in a large cohort of CKD patients.

Most population-based studies are consistent with an impact of aortic stiffness on incident CKD but not on CKD progression. In The Health ABS study, which included 2,129 older adults (mean age $74 \pm 3$ years, mean eGFR $79 \pm 19 \mathrm{ml} / \mathrm{min} / 1.73 \mathrm{~m}^{2}$, median follow-up 8.9 years), carotid-femoral PWV was not associated with rapid GFR decline but with incident CKD [53]. This was confirmed in a recent general population study in which aortic stiffness was associated with incident CKD but not with GFR decline. More precisely, pulse pressure, carotid stiffness and aortic stiffness were measured in 3,666 participants of the Rotterdam study. The mean follow-up was 11 years. 601 incident CKD cases were registered. Each SD higher carotid-femoral PWV was associated with a 7\% higher risk of incident CKD $(95 \% \mathrm{CI}$, 1.00-1.14). No association was seen between carotid-femoral PWV and kidney function decline. Only carotid stiffness was independently associated with GFR decline [54]. The longitudinal analyses of the Framingham Heart Offspring cohort ( $n=1,675$ and $n=1,252$, followup 7-10 years) are the exception since they did not show an association between baseline carotid-femoral PWV and incident CKD or incident microalbuminuria [55].

Despite controversial results from CKD cohorts and a population-based study about the impact of aortic stiffness measured by carotid-femoral PWV on renal injury, most clinical and 
Table 3. Longitudinal studies evaluating the impact of aortic stiffness on GFR decline

\begin{tabular}{|c|c|c|c|c|}
\hline Study & $\begin{array}{l}\text { Patients, } \\
\mathrm{n}\end{array}$ & $\begin{array}{l}\text { Mean age, eGFR, mean } \\
\text { follow-up }\end{array}$ & Multivariate models & Impact of CF-PWV on CKD progression \\
\hline $\begin{array}{l}\text { The NephroTest } \\
\text { study [46] }\end{array}$ & 180 & $\begin{array}{l}56.6(14.2) \text { years } \\
32(16) \mathrm{ml} / \mathrm{min} / 1.73 \mathrm{~m}^{2} \\
3.5 \text { years }\end{array}$ & $\begin{array}{l}\text { Baseline GFR, gender, age, BMI, } \\
\text { smoking, diabetes, dyslipidemia, } \\
\text { MBP }\end{array}$ & $\begin{array}{l}\text { No independent association between } \\
\text { CF-PWV and CKD progression } \\
\text { Independent association between } \\
\text { circumferential wall stress and CKD } \\
\text { progression and ESRD } \\
\text { Independent association between } \\
\text { central pulse pressure and ESRD }\end{array}$ \\
\hline Ford et al. [52] & 133 & $\begin{array}{l}69(12) \text { years } \\
32(11) \mathrm{ml} / \mathrm{min} / 1.73 \mathrm{~m}^{2} \\
1.5 \text { years }\end{array}$ & $\begin{array}{l}\text { SBP, uPCR, diabetes, smoking, } \\
\text { gender }\end{array}$ & $\begin{array}{l}\text { Independent association between } \\
\text { CF-PWV and CKD progression }\end{array}$ \\
\hline Bauman et al. [51] & 135 & $\begin{array}{l}59.2(15.1) \text { years } \\
48(24) \mathrm{ml} / \mathrm{min} / 1.73 \mathrm{~m}^{2} \\
3.5 \text { years }\end{array}$ & $\begin{array}{l}\text { Baseline eGFR, gender, age, DBP, } \\
\text { RAS antihypertensive therapy }\end{array}$ & $\begin{array}{l}\text { No independent association between } \\
\text { CF-PWV and ESRD }\end{array}$ \\
\hline $\begin{array}{l}\text { The Framingham } \\
\text { Offspring cohort } \\
{[55]}\end{array}$ & $\begin{array}{l}1,675 / \\
1,252\end{array}$ & $51 \mathrm{ml} / \mathrm{min} / 1.73 \mathrm{~m}^{2}$ & $\begin{array}{l}\text { Baseline eGFR, gender, age, BMI, } \\
\text { HR, MBP, diabetes, fasting } \\
\text { glucose, total/HDL CT, TG, lipid } \\
\text { lowering medication use, } \\
\text { hypertension treatment, } \\
\text { hormone replacement therapy, } \\
\text { current smoking status, and } \\
\text { prevalent CVD }\end{array}$ & $\begin{array}{l}\text { No independent association between } \\
\text { CF-PWV and incident CKD or incident } \\
\text { microalbuminuria }\end{array}$ \\
\hline $\begin{array}{l}\text { The Health } \mathrm{ABC} \\
\text { study [53] }\end{array}$ & 2,129 & $\begin{array}{l}74(3) \text { years } \\
71(21) \mathrm{ml} / \mathrm{min} / 1.73 \mathrm{~m}^{2} \\
3 \text { and } 10 \text { years }\end{array}$ & $\begin{array}{l}\text { Age, gender, race, site, } \\
\text { antihypertensive medications, } \\
\text { diabetes, smoking, LDL, HDL, } \\
\text { prevalent coronary heart disease, } \\
\text { prevalent heart failure, MBP }\end{array}$ & $\begin{array}{l}\text { No independent association between } \\
\text { CF-PWV and GFR decline } \\
\text { Independent association between } \\
\text { CF-PWV and incident CKD } \\
\text { Independent association between } \\
\text { peripheral pulse pressure and GFR } \\
\text { decline } \\
\text { Independent association between } \\
\text { peripheral pulse pressure and incident } \\
\text { CKD }\end{array}$ \\
\hline $\begin{array}{l}\text { The Rotterdam } \\
\text { study [54] }\end{array}$ & 3,666 & $\begin{array}{l}65.0(6.7) \text { years } \\
79.3(13.7) \mathrm{ml} / \mathrm{min} / \\
1.73 \mathrm{~m}^{2} \\
11 \text { years }\end{array}$ & $\begin{array}{l}\text { Age, gender, MBP, HR, baseline } \\
\text { eGFR, follow-up time, BMI, } \\
\text { alcohol consumption, smoking, } \\
\text { total/HDL CT, diuretics, ACE } \\
\text { inhibitors, beta-blockers, calcium } \\
\text { channel blockers, history of } \\
\text { diabetes, and CHD }\end{array}$ & $\begin{array}{l}\text { No independent association between } \\
\text { CF-PWV and GFR decline } \\
\text { Each SD higher CF-PWV was associated } \\
\text { with 7\% higher risk in incident CKD } \\
\text { Independent association between } \\
\text { peripheral pulse pressure and GFR } \\
\text { decline } \\
\text { Independent association between } \\
\text { peripheral pulse pressure and incident } \\
\text { CKD }\end{array}$ \\
\hline
\end{tabular}

Figures in parentheses indicate SD. BMI = Body mass index; SBP = systolic blood pressure; DBP = diastolic blood pressure; MBP = mean blood pressure; uPCR = urinary protein-to-creatinine ratio; CF-PWV = carotid-femoral PWV; CHD = coronary heart disease; $\mathrm{HR}=$ heart rate; $\mathrm{CT}=$ cholesterol; $\mathrm{TG}=$ triglycerides.

epidemiological studies confirmed that brachial and/or central pulse pressure exerts a negative impact on the kidney, on the rate of GFR decline [46, 53, 55], on incident ESRD [46] and CKD [53].

Looking only at arterial stiffness may provide a limited view of the arterial disease associated with CKD. In CKD patients, arterial remodeling has been characterized by outward 
remodeling with an enlargement of lumen diameter $[39,48]$. Outward remodeling may be a defense mechanism to prevent the loss of buffering capacity in the event of a decrease in distensibility. However, in CKD patients, arterial enlargement was not associated with arterial thickening. This feature defines pressure-unadapted arterial remodeling [19, 39] and leads to an increase in circumferential wall stress according to the Lame equation. The longitudinal follow-up of aortic and carotid remodeling parameters in the NephroTest cohort confirmed that unadapted arterial remodeling progressed over time with a significant increase in lumen diameter and circumferential wall stress, and a significant decrease in carotid intima-media thickness. Interestingly, the rate of intima thickness decline was fast $(-22 \mu \mathrm{m} / \mathrm{year})$ and matched the increase in intima-media thickness observed in high CV risk patients without CKD, but in an opposite way $[46,56]$. The mechanisms underlying the defect in arterial wall thickening are unclear. Accelerated extracellular matrix turnover, a lack of vascular smooth muscle cell proliferation or excess apoptosis have been suggested. This process impacts patient prognosis since circumferential wall stress has been independently associated with a higher rate of GFR decline.

\section{Impact of Aortic Stiffness on CV and General Prognosis}

Numerous lines of evidence link arterial stiffness measured by carotid-femoral PWV and general and CV prognosis in the general population and in different subgroups of patients including, among others, essential hypertensive patients [26,27], patients with type 2 diabetes [25] and elderly subjects [28].

In ESRD, increased arterial stiffness, determined by the measurement of carotid-femoral PWV, is a powerful independent predictor of all-cause mortality and CV events in hemodialysis patients $[16,57,58]$ and peritoneal dialysis patients [59]. Improvement of carotidfemoral PWV has been associated with a better general prognosis in hemodialysis patients [60].

The same observations have been published in patients with stages 2-5 CKD. In the Atherosclerosis and Folic Acid Supplementation Trial, 315 patients with CKD stages 4-5, mean age $56.6 \pm 13.6$ years, had indices of arterial stiffness measurements, including aortofemoral PWV, systemic arterial compliance and carotid-derived augmentation index, and CV event recording during a median follow-up of 3.6 years. After adjustment for classical CV risk factors, aortofemoral PWV remained the only independent predictor of CV events [61]. In the NephroTest cohort, carotid-femoral PWV was also an independent predictor of all-cause mortality [for 1 SD, Cox model-derived relative risk (95\% CI), 1.48 (1.09-2.02)] and fatal and nonfatal CV events [for 1 SD, Fine and Gray competing risks model-derived relative risk (95\% CI), 1.35 (1.05-1.75)]. Interestingly, the net reclassification improvement index was significant, meaning that measuring carotid-femoral PWV in CKD patients improves the prediction of risk beyond classical CV risk factors [17]. An association between aortic stiffness and CV events was also seen in the CRIC study [18].

\section{Aortic Stiffness Progression after Renal Transplantation}

The renal transplant recipient population is a very specific population in whom renal function is greatly improved compared with ESRD patients, even if the restoration of normal GFR is often incomplete. Renal transplantation improves survival and decreases CV events compared with hemodialysis $[62,63]$, but CV risk is still high compared with the general population. Indeed, this population is exposed to nontraditional CV risk factors related to the 
donor and recipient: donor factors such as age, renal and vascular status, graft rejection and immunosuppressive drugs [64-66]. In renal transplant recipients, aortic PWV is also a strong and independent predictor of all-cause mortality and CV events $[67,68]$.

The evolution of arterial stiffness and remodeling markers after renal transplantation is still a matter of debate $[64,65]$. The improvement of aortic stiffness in kidney transplant recipients is not obvious. Donor age, improvement of blood pressure and donor characteristics - living/cadaveric - are major determinants of aortic stiffness progression after transplantation. Delahousse et al. [64] measured carotid-femoral PWV in a cohort of 74 cadaveric kidney recipients at 3 and 12 months after transplantation. At 3 months, mean eGFR was 65 $\pm 18 \mathrm{ml} / \mathrm{min} / 1.73 \mathrm{~m}^{2}$ and at $12 \mathrm{months} 68 \pm 22 \mathrm{ml} / \mathrm{min} / 1.73 \mathrm{~m}^{2}$. In the entire population, carotid-femoral PWV did not change significantly between 3 and 12 months. By contrast, carotid-femoral PWV decreased by $0.43 \mathrm{~m} / \mathrm{s}$ between 3 and 12 months in recipients with young-donor kidney but increased in recipients with old-donor kidney. The association between carotid-femoral PWV and donor age was independent of recipient age, gender, mean blood pressure, pretransplantation dialysis duration, CV risk factors and eGFR [64]. In another cohort of 36 renal transplant recipients (mean age $46 \pm 11$ years, mean eGFR at 12 months $60 \pm 16 \mathrm{ml} / \mathrm{min} / 1.73 \mathrm{~m}^{2}$ ), carotid-femoral PWV significantly improved 1 year after transplantation. However, carotid-femoral PWV change was no longer significant after adjustment to blood pressure [69]. In a recent communication at the European Society of Hypertension meeting in 2015, Karras et al. [70] emphasized the impact of live organ donation on arterial remodeling parameter improvement 12 months after kidney transplantation.

\section{Conclusion}

Aortic stiffness is increased in CKD at any stage and in transplant recipients. Its impact on general and CV prognosis is widely accepted. Carotid-femoral PWV measurements even improve the prediction of CV risk in CKD patients beyond the traditional and renal CV risk factors. However, conflicting results have been published about the relationship between aortic stiffness and eGFR within the CKD population. The heterogeneity of the CKD study population partly explains these observations. Individual meta-analyses may help to disentangle the relationship between aortic stiffness and eGFR in different subgroups of CKD patients.

\section{Disclosure Statement}

The authors declare that they have no conflicts of interest.

\section{References}

1 Levey AS, de Jong PE, Coresh J, El Nahas M, Astor BC, Matsushita K, Gansevoort RT, Kasiske BL, Eckardt KU: The definition, classification and prognosis of chronic kidney disease: a KDIGO Controversies Conference report. Kidney Int 2011;80:17-28.

2 Jha V, Garcia-Garcia G, Iseki K, Li Z, Naicker S, Plattner B, Saran R, Wang AY, Yang CW: Chronic kidney disease: global dimension and perspectives. Lancet 2013;382:260-272.

3 Parsa A, Kao WH, Xie D, Astor BC, Li M, Hsu CY, Feldman HI, Parekh RS, Kusek JW, Greene TH, Fink JC, Anderson AH, Choi MJ, Wright JT Jr, Lash JP, Freedman BI, Ojo A, Winkler CA, Raj DS, Kopp JB, He J, Jensvold NG, Tao K, Lipkowitz MS, Appel LJ: APOL1 risk variants, race, and progression of chronic kidney disease. N Engl J Med 2013;369:2183-2196.

4 Keith DS, Nichols GA, Gullion CM, Brown JB, Smith DH: Longitudinal follow-up and outcomes among a population with chronic kidney disease in a large managed care organization. Arch Intern Med 2004;164:659-663. 
5 Foley RN, Parfrey PS, Sarnak MJ: Clinical epidemiology of cardiovascular disease in chronic renal disease. Am J Kidney Dis 1998;32:S112-S119.

6 Go AS, Chertow GM, Fan D, McCulloch CE, Hsu CY: Chronic kidney disease and the risks of death, cardiovascular events, and hospitalization. N Engl J Med 2004;351:1296-1305.

7 Matsushita K, Van Der Velde M, Astor BC, Woodward M, Levey AS, de Jong PE, Coresh J, Gansevoort RT: Association of estimated glomerular filtration rate and albuminuria with all-cause and cardiovascular mortality in general population cohorts: a collaborative meta-analysis. Lancet 2010;375:2073-2081.

8 Shemin D, Bostom AG, Laliberty P, Dworkin LD: Residual renal function and mortality risk in hemodialysis patients. Am J Kidney Dis 2001;38:85-90.

9 Sud M, Tangri N, Pintilie M, Levey AS, Naimark D: Risk of end-stage renal disease and death after cardiovascular events in chronic kidney disease. Circulation 2014;130:458-465.

10 Wanner C, Krane V, Marz W, Olschewski M, Mann JF, Ruf G, Ritz E: Atorvastatin in patients with type 2 diabetes mellitus undergoing hemodialysis. N Engl J Med 2005;353:238-248.

11 Fellstrom BC, Jardine AG, Schmieder RE, Holdaas H, et al: Rosuvastatin and cardiovascular events in patients undergoing hemodialysis. N Engl J Med 2009;360:1395-1407.

12 Chertow GM, Block GA, Correa-Rotter R, Drueke TB, Floege J, Goodman WG, Herzog CA, Kubo Y, London GM, Mahaffey KW, Mix TC, Moe SM, Trotman ML, Wheeler DC, Parfrey PS: Effect of cinacalcet on cardiovascular disease in patients undergoing dialysis. N Engl J Med 2012;367:2482-2494.

13 de Zeeuw D, Akizawa T, Audhya P, Bakris GL, Chin M, Christ-Schmidt H, Goldsberry A, Houser M, Krauth M, Lambers Heerspink HJ, McMurray JJ, Meyer CJ, Parving HH, Remuzzi G, Toto RD, Vaziri ND, Wanner C, Wittes J, Wrolstad D, Chertow GM: Bardoxolone methyl in type 2 diabetes and stage 4 chronic kidney disease. N Engl J Med 2013;369:2492-2503.

14 Schiffrin EL, Lipman ML, Mann JF: Chronic kidney disease: effects on the cardiovascular system. Circulation 2007;116:85-97.

15 London GM, Guerin AP, Marchais SJ, Pannier B, Safar ME, Day M, Metivier F: Cardiac and arterial interactions in end-stage renal disease. Kidney Int 1996;50:600-608.

16 Blacher J, Guerin AP, Pannier B, Marchais SJ, Safar ME, London GM: Impact of aortic stiffness on survival in end-stage renal disease. Circulation 1999;99:2434-2439.

17 Karras A, Haymann JP, Bozec E, Metzger M, Jacquot C, Maruani G, Houillier P, Froissart M, Stengel B, Guardiola $\mathrm{P}$, Laurent S, Boutouyrie P, Briet M: Large artery stiffening and remodeling are independently associated with all-cause mortality and cardiovascular events in chronic kidney disease. Hypertension 2012;60:1451-1457.

18 Chirinos JA, Khan A, Bansal N, Dries DL, Feldman HI, Ford V, Anderson AH, Kallem R, Lash JP, Ojo A, Schreiber M, Sheridan A, Strelsin J, Teal V, Roy J, Pan Q Go AS, Townsend RR: Arterial stiffness, central pressures, and incident hospitalized heart failure in the chronic renal insufficiency cohort study. Circ Heart Fail 2014;7:709-716.

19 Briet M, Boutouyrie P, Laurent S, London GM: Arterial stiffness and pulse pressure in CKD and ESRD. Kidney Int 2012;82:388-400.

20 London GM, Pannier B: Arterial functions: how to interpret the complex physiology. Nephrol Dial Transplant 2010;25:3815-3823.

21 Laurent S, Boutouyrie P: The structural factor of hypertension: large and small artery alterations. Circ Res 2015;116:1007-1021.

22 Tomlinson LA: Methods for assessing arterial stiffness: technical considerations. Curr Opin Nephrol Hypertens 2012;21:655-660.

23 Laurent S, Cockcroft J, Van Bortel L, Boutouyrie P, Giannattasio C, Hayoz D, Pannier B, Vlachopoulos C, Wilkinson I, Struijker-Boudier H: Expert consensus document on arterial stiffness: methodological issues and clinical applications. Eur Heart J 2006;27:2588-2605.

24 Van Bortel LM, Laurent S, Boutouyrie P, Chowienczyk P, Cruickshank JK, De Backer T, Filipovsky J, Huybrechts S, Mattace-Raso FU, Protogerou AD, Schillaci G, Segers P, Vermeersch S, Weber T: Expert consensus document on the measurement of aortic stiffness in daily practice using carotid-femoral pulse wave velocity. J Hypertens 2012;30:445-448.

25 Cruickshank K, Riste L, Anderson SG, Wright JS, Dunn G, Gosling RG: Aortic pulse-wave velocity and its relationship to mortality in diabetes and glucose intolerance: an integrated index of vascular function? Circulation 2002;106:2085-2090.

26 Boutouyrie P, Tropeano AI, Asmar R, Gautier I, Benetos A, Lacolley P, Laurent S: Aortic stiffness is an independent predictor of primary coronary events in hypertensive patients: a longitudinal study. Hypertension 2002;39:10-15.

27 Laurent S, Boutouyrie P, Asmar R, Gautier I, Laloux B, Guize L, Ducimetiere P, Benetos A: Aortic stiffness is an independent predictor of all-cause and cardiovascular mortality in hypertensive patients. Hypertension 2001; 37:1236-1241.

28 Vlachopoulos C, Aznaouridis K, Stefanadis C: Prediction of cardiovascular events and all-cause mortality with arterial stiffness: a systematic review and meta-analysis. J Am Coll Cardiol 2010;55:1318-1327.

29 Gibbons GH, Dzau VJ: The emerging concept of vascular remodeling. N Engl J Med 1994;330:1431-1438.

30 Determinants of pulse wave velocity in healthy people and in the presence of cardiovascular risk factors: 'establishing normal and reference values. Eur Heart J 2010;31:2338-2350. 
31 Mancia G, De Backer G, Dominiczak A, Cifkova R, et al: 2007 Guidelines for the Management of Arterial Hypertension: The Task Force for the Management of Arterial Hypertension of the European Society of Hypertension (ESH) and of the European Society of Cardiology (ESC). J Hypertens 2007;25:1105-1187.

32 Mancia G, Fagard R, Narkiewicz K, Redon J, et al: 2013 ESH/ESC guidelines for the management of arterial hypertension: the Task Force for the Management of Arterial Hypertension of the European Society of Hypertension (ESH) and of the European Society of Cardiology (ESC). Eur Heart J 2013;34:2159-2219.

33 Londono F, Bossuyt J, Engelen L, Stehouwer C, Ferreira I, Laurent S, Boutouyrie P, Segers P, Van Bortel L: 4d.01: A simple calculator for the assessment of measurements of carotid-femoral pulse wave velocity and local arterial stiffness relative to the reference values database. J Hypertens 2015;33(suppl 1):e60-e.

34 London GM, Marchais SJ, Safar ME, Genest AF, Guerin AP, Metivier F, Chedid K, London AM: Aortic and large artery compliance in end-stage renal failure. Kidney Int 1990;37:137-142.

35 Lindner A, Charra B, Sherrard DJ, Scribner BH: Accelerated atherosclerosis in prolonged maintenance hemodialysis. N Engl J Med 1974;290:697-701.

36 London GM, Guerin AP, Pannier B, Marchais SJ, Safar ME: Large artery structure and function in hypertension and end-stage renal disease. J Hypertens 1998;16:1931-1938.

37 Fortier C, Mac-Way F, Desmeules S, Marquis K, De Serres SA, Lebel M, Boutouyrie P, Agharazii M: Aorticbrachial stiffness mismatch and mortality in dialysis population. Hypertension 2015;65:378-384.

38 Utescu MS, Couture V, Mac-Way F, De Serres SA, Marquis K, Lariviere R, Desmeules S, Lebel M, Boutouyrie P, Agharazii M: Determinants of progression of aortic stiffness in hemodialysis patients: a prospective longitudinal study. Hypertension 2013;62:154-160.

39 Briet M, Bozec E, Laurent S, Fassot C, London GM, Jacquot C, Froissart M, Houillier P, Boutouyrie P: Arterial stiffness and enlargement in mild-to-moderate chronic kidney disease. Kidney Int 2006;69:350-357.

40 Shinohara K, Shoji T, Tsujimoto Y, Kimoto E, Tahara H, Koyama H, Emoto M, Ishimura E, Miki T, Tabata T, Nishizawa Y: Arterial stiffness in predialysis patients with uremia. Kidney Int 2004;65:936-943.

41 Wang MC, Tsai WC, Chen JY, Huang JJ: Stepwise increase in arterial stiffness corresponding with the stages of chronic kidney disease. Am J Kidney Dis 2005;45:494-501.

42 Townsend RR, Wimmer NJ, Chirinos JA, Parsa A, Weir M, Perumal K, Lash JP, Chen J, Steigerwalt SP, Flack J, Go AS, Rafey M, Rahman M, Sheridan A, Gadegbeku CA, Robinson NA, Joffe M: Aortic PWV in chronic kidney disease: a CRIC ancillary study. Am J Hypertens 2010;23:282-289.

43 Weir MR, Townsend RR, Fink JC, Teal V, Anderson C, Appel L, Chen J, He J, Litbarg N, Ojo A, Rahman M, Rosen L, Sozio SM, Steigerwalt S, Strauss L, Joffe MM: Hemodynamic correlates of proteinuria in chronic kidney disease. Clin J Am Soc Nephrol 2011;6:2403-2410.

44 Matsuda N, Takei T, Fujiu A, Ogawa T, Nitta K: Arterial stiffness in patients with non-diabetic chronic kidney disease (CKD). J Atheroscler Thromb 2009;16:57-62.

45 Sengstock D, Sands RL, Gillespie BW, Zhang X, Kiser M, Eisele G, Vaitkevicius P, Kuhlmann M, Levin NW, Hinderliter A, Rajagopalan S, Saran R: Dominance of traditional cardiovascular risk factors over renal function in predicting arterial stiffness in subjects with chronic kidney disease. Nephrol Dial Transplant 2010;25:853861.

46 Briet M, Collin C, Karras A, Laurent S, Bozec E, Jacquot C, Stengel B, Houillier P, Froissart M, Boutouyrie P: Arterial remodeling associates with CKD progression. J Am Soc Nephrol 2011;22:967-974.

47 Lilitkarntakul P, Dhaun N, Melville V, Blackwell S, Talwar DK, Liebman B, Asai T, Pollock J, Goddard J, Webb DJ: Blood pressure and not uraemia is the major determinant of arterial stiffness and endothelial dysfunction in patients with chronic kidney disease and minimal co-morbidity. Atherosclerosis 2011;216:217-225.

48 Hermans MM, Henry R, Dekker JM, Kooman JP, Kostense PJ, Nijpels G, Heine RJ, Stehouwer CD: Estimated glomerular filtration rate and urinary albumin excretion are independently associated with greater arterial stiffness: the Hoorn Study. J Am Soc Nephrol 2007;18:1942-1952.

49 Mourad JJ, Pannier B, Blacher J, Rudnichi A, Benetos A, London GM, Safar ME: Creatinine clearance, pulse wave velocity, carotid compliance and essential hypertension. Kidney Int 2001;59:1834-1841.

50 Bidani AK, Griffin KA, Williamson G, Wang X, Loutzenhiser R: Protective importance of the myogenic response in the renal circulation. Hypertension 2009;54:393-398.

51 Baumann M, Wassertheurer S, Suttmann Y, Burkhardt K, Heemann U: Aortic pulse wave velocity predicts mortality in chronic kidney disease stages 2-4. J Hypertens 2014;32:899-903.

52 Ford ML, Tomlinson LA, Chapman TP, Rajkumar C, Holt SG: Aortic stiffness is independently associated with rate of renal function decline in chronic kidney disease stages 3 and 4. Hypertension 2010;55:11101115.

53 Madero M, Peralta C, Katz R, Canada R, Fried L, Najjar S, Shlipak M, Simonsick E, Lakatta E, Patel K, Rifkin D, Hawkins M, Newman A, Sarnak M: Association of arterial rigidity with incident kidney disease and kidney function decline: the Health ABC study. Clin J Am Soc Nephrol 2013;8:424-433.

54 Sedaghat S, Mattace-Raso FU, Hoorn EJ, Uitterlinden AG, Hofman A, Ikram MA, Franco OH, Dehghan A: Arterial stiffness and decline in kidney function. Clin J Am Soc Nephrol 2015;10:2190-2197.

55 Upadhyay A, Hwang SJ, Mitchell GF, Vasan RS, Vita JA, Stantchev PI, Meigs JB, Larson MG, Levy D, Benjamin EJ, Fox CS: Arterial stiffness in mild-to-moderate CKD. J Am Soc Nephrol 2009;20:2044-2053.

56 Mack WJ, Selzer RH, Hodis HN, Erickson JK, Liu CR, Liu CH, Crawford DW, Blankenhorn DH: One-year reduction and longitudinal analysis of carotid intima-media thickness associated with colestipol/niacin therapy. Stroke 1993;24:1779-1783. 
57 Shoji T, Emoto M, Shinohara K, Kakiya R, Tsujimoto Y, Kishimoto H, Ishimura E, Tabata T, Nishizawa Y: Diabetes mellitus, aortic stiffness, and cardiovascular mortality in end-stage renal disease. J Am Soc Nephrol 2001;12: 2117-2124.

58 Pannier B, Guerin AP, Marchais SJ, Safar ME, London GM: Stiffness of capacitive and conduit arteries: prognostic significance for end-stage renal disease patients. Hypertension 2005;45:592-596.

59 Sipahioglu MH, Aybal A, Unal A, Tokgoz B, Oymak O, Utas C: Patient and technique survival and factors affecting mortality on peritoneal dialysis in Turkey: 12 years' experience in a single center. Perit Dial Int 2008;28:238245.

60 Guerin AP, Blacher J, Pannier B, Marchais SJ, Safar ME, London GM: Impact of aortic stiffness attenuation on survival of patients in end-stage renal failure. Circulation 2001;103:987-992.

61 Zoungas S, Cameron JD, Kerr PG, Wolfe R, Muske C, McNeil JJ, McGrath BP: Association of carotid intima-medial thickness and indices of arterial stiffness with cardiovascular disease outcomes in CKD. Am J Kidney Dis 2007; 50:622-630.

62 Wolfe RA, Ashby VB, Milford EL, Ojo AO, Ettenger RE, Agodoa LY, Held PJ, Port FK: Comparison of mortality in all patients on dialysis, patients on dialysis awaiting transplantation, and recipients of a first cadaveric transplant. N Engl J Med 1999;341:1725-1730.

63 Meier-Kriesche HU, Schold JD, Srinivas TR, Reed A, Kaplan B: Kidney transplantation halts cardiovascular disease progression in patients with end-stage renal disease. Am J Transplant 2004;4:1662-1668.

64 Delahousse M, Chaignon M, Mesnard L, Boutouyrie P, Safar ME, Lebret T, Pastural-Thaunat M, Tricot L, KolkoLabadens A, Karras A, Haymann JP: Aortic stiffness of kidney transplant recipients correlates with donor age. J Am Soc Nephrol 2008;19:798-805.

65 Kneifel M, Scholze A, Burkert A, Offermann G, Rothermund L, Zidek W, Tepel M: Impaired renal allograft function is associated with increased arterial stiffness in renal transplant recipients. Am J Transplant 2006;6: 1624-1630.

66 Bahous SA, Stephan A, Barakat W, Blacher J, Asmar R, Safar ME: Aortic pulse wave velocity in renal transplant patients. Kidney Int 2004;66:1486-1492.

67 Mitchell A, Opazo Saez A, Kos M, Witzke O, Kribben A, Nurnberger J: Pulse wave velocity predicts mortality in renal transplant patients. Eur J Med Res 2010;15:452-455.

68 Verbeke F, Marechal C, Van Laecke S, Van Biesen W, Devuyst O, Van Bortel LM, Jadoul M, Vanholder R: Aortic stiffness and central wave reflections predict outcome in renal transplant recipients. Hypertension 2011;58: 833-838.

69 Zoungas S, Kerr PG, Chadban S, Muske C, Ristevski S, Atkins RC, McNeil JJ, McGrath BP: Arterial function after successful renal transplantation. Kidney Int 2004;65:1882-1889.

70 Karras A, Boutouyrie P, Briet M, Bozec E, Legendre C, McMahon L, Delahousse M: 4d.05: recovery of vascular health after kidney transplantation. J Hypertens 2015;33(suppl 1):e61-e62. 